\title{
Title Health Priority-Setting For Overseas \\ Development Assistance in Low-Income and Middle-Income Countries: A Comparative Case Study of Ethiopia, Nigeria and Tanzania
}

Xiaoxiao Jiang Kwete ( $\nabla$ xiaoxiao@mail.harvard.edu )

Harvard TH Chan School of Public Health

Yemane Berhane

Addis Continental Institute of Public Health

Mary Mwanyika-Sando

Africa Academy for Public Health

Ayo Oduola

University of Ibadan Research Foundation

Yuning Liu

JPMorgan Chase Institute

Firehiwot Workneh

Addis Continental Institute of Public Health

Smret Hagos

Addis Continental Institute of Public Health

Japhet Killewo

Muhimbili University of Health and Allied Sciences

Dominic Mosha

Africa Academy for Public Health

Angela Chukwu

University of Ibadan Research Foundation

Kabiru Salami

University of Ibadan Research Foundation

Bidemi Yusuf

University of Ibadan Research Foundation

Kun Tang

Tsinghua University Vanke School of Public Health

Zhi-Jie Zheng

Peking University School of Public Health

Rifat Atun

Harvard TH Chan School of Public Health 


\section{Wafaie Fawzi}

Harvard TH Chan School of Public Health

\section{Research Article}

Keywords: priority setting, overseas development assistance, qualitative case study, health systems

Posted Date: April 21st, 2021

DOl: https://doi.org/10.21203/rs.3.rs-403890/v1

License: (c) (1) This work is licensed under a Creative Commons Attribution 4.0 International License. Read Full License 


\section{Abstract}

Background Priority setting process for the health care sector in low- and middle-income countries involves multiple agencies, each with their unique power, decision-making and funding mechanisms.

Methods This paper developed and applied a new framework to analyze priority setting processes in Ethiopia, Nigeria, and Tanzania, from a scoping review of literature. Interviews were then conducted using a pre-determined interview guide developed by the research team. Transcripts were reviewed and coded based on the framework to identify what principles, players, processes, and products were considered during priority setting. Those elements were further used to identify where the potential capacity of local decision-makers could be harnessed.

Results a framework was developed based on 40 articles selected from 6860 distinct search records. 21 interviews were conducted in three case countries from 12 institutions. Transcripts or meeting notes were analyzed to identify common practices and specific challenges faced by each country. We found that multiple stakeholders working around one national plan was the preferred approach used for priority setting in the countries studied.

Conclusions Priority setting process can be further strengthened through better use of analytical tools, such as the one described in our study, to enhance local ownership and improve aid effectiveness.

\section{Background:}

Overseas Development Assistance (ODA) is an important contribution to health financing in many lowand middle-income countries (LMICs)(1-3). Although most LMICs have been able to achieve the Millennium Development Goals (MDGs) with the support of the global community, the association between improvements of MDG indicators and development assistance have yielded mixed results (4-7).

Given the large amount of funds used in ODA and the mixed results, it is important to understand how ODA is applied, to ensure scarce resources are used efficiently in addressing the most pressing health needs in LMICs. Since the Paris Declaration(8), Accra Agenda for Action(8), and subsequent international agreements relating to ODA, the global development community has reached a consensus that local ownership and ODA alignment to national strategies and plans are key to sustainable development. Nonetheless, there is a persistent tension between donor countries providing ODA and governments in the recipient countries on how ODA should be allocated, as priority setting for health in recipient countries is still heavily influenced by donor interests, and in some the process is donor-driven (9-13). The power asymmetry between the donor and recipient countries can explicitly or implicitly impact the behavior of institutions receiving $\mathrm{ODA}(14,15)$.

The Paris Declaration has prompted the development of different standards and initiatives to change donor behavior to respect local ownership and better align ODA to local priorities - including Sector Wide Approaches (SWAPs) and the International Health Partnership Plus (IHP+) - but studies examining 
changes in donor behavior have revealed mixed outcomes on achieving goals set in the Paris Declaration (16-19).

While there are studies (20-24) which have examined the systematic approaches used by donor countries to set their priorities and influence agenda of recipient governments, or the frameworks proposed by academic scholars(25), few studies have examined priority setting processes in recipient countries from the perspective of local governments to ascertain how they align or differ from the priorities identified by global agencies or donor countries.

Policy formulation involves intricate processes that results-focused and purely quantitative evaluation studies fail to account for or capture(26-29). Weak stewardship and governance hinders effective priority setting processes for health in recipient governments and local agencies and impacts adversely on the use of available ODA (30).

Based on a scoping review undertaken as part of this study, the authors developed and applied an analytical framework in studies in Ethiopia, Nigeria and Tanzania for examination and comparative assessment of priority setting process in relation to ODA to ascertain donor and local influences on decision making.

\section{Methods:}

\section{Study design:}

A scoping review was conducted using the Arksey and O'Mally method(31) to identify relevant published articles from PubMed, Embase and Web of Science (Thomson)using the following search terms: 1) lowand middle-income countries, 2) external funding and aid, 3) health, and 4) tools and processes.

Two researchers (XK and $\mathrm{YL}$ ) independently reviewed the abstracts of the articles retrieved by the search and selected those which were relevant to the research topic and extracted keywords. Differences in the articles selected for detailed full-text examination by the two independent reviewers were discussed and any differences were resolved.

Conventional qualitative content analysis and grounded theory method(32-34) was used to analyze the data extracted from the articles selected for full-text analysis. The keywords which emerged from the articles selected for full-text analysis were compared and synthesized into major thematic categories to develop the final analytical framework.

Ethiopia, Nigeria, and Tanzania were selected as the three country case studies for in-depth analysis of priority setting and for examination of dispute settling mechanisms used by national and local governments to reconcile priorities of donors providing external funding for health.

Qualitative data were collected in the three study countries using in-depth interviews of selected key informants. 


\section{Sampling}

We used purposive sampling with snowballing. List of institutions were selected through a combined method of a pre-determined list by the research team as well as recommendations by interviewees.

We purposefully selected key informants from organizations and departments involved in planning, managing and overseeing the receiving and implementation of external funding for health. They included officials from departments or organizations that are involved in managing and overseeing the receiving and implementation of external funding for health. Since there was only a limited list of entities involved in this process, no random sampling was required but instead purposive sampling with snowballing was used to reach key informants.

The interviews were initially conducted with key informants who worked in the main department(s) or organization(s) that managed and oversaw external funds. Snowballing methodology was used to identify and interview additional key informants in all departments and organizations involved in priority setting process. These additional key informants were identified by those in the main department involved in the first round of interviews.

\section{Data collection:}

All interviews were conducted in person using a pre-determined interview guide. The interviews in Ethiopia were conducted in Amharic by public health researchers fluent in speaking, reading, and writing in Amharic. The interviews in Nigeria were conducted in English and in Tanzania in Swahili.

For those who consented to audio recording, the recording was transcribed in full text. For those who did not give consent to audio recording, meeting notes were taken contemporaneously by the research team undertaking interviews in the respective country.

In Nigeria, a state was selected for sub-national government departments interviews, as the decisionmaking process was de-centralized, as assessed by the local research team.

\section{Data analysis:}

A framework developed by the authors from the scoping literature review as was described earlier was used for analyzing priority setting process of local governments. Qualitative data from interviews was summarized by the layers and themes presented in the framework following conventional qualitative content analysis(32) method: frequencies of keywords were documented together with key quotations that correspond to each of the theme, and compared across themes, layers and countries to identify strength or weakness areas.

\section{Results:}

Scoping Review and Framework Development: 
The systematic scoping review yielded 8170 results across three databases (1886 from Pubmed, 197 from Embase, and 6087 from Web of Sciences). The search was completed on September 10th, 2018. After removal of 1310 duplicates, 6860 distinct records were retrieved for review following the criteria specified above and generated 79 articles for full-text review. Data extraction and narrative synthesis was conducted on a final list of 40 articles (Fig. 1).

All 40 articles described the priority setting process of a LMIC government agency and 15 of them also described how they resolved disagreements with ODA sponsors. Thirty-five (35) of them covered a single LMIC and 5 covered multiple countries. Of the 35 articles that covered single country cases, $25(71 \%)$ of the studies were in Africa, 8 (23\%) in Asia and 2(6\%) in Latin America.

Close to 20 sub-themes were extracted and further categorized into four tiers of themes (namely, Principles, Players, Processes, and Products), each answering a different question related to the process of priority setting. Based on those themes extracted from the text, we developed a framework for analyzing the priority setting process of local governments. It consists of four layers of elements: 1) principles, which shape the global, regional and local context (such as Paris Principles, Accra Agenda for Action, and IHP + which has informed the development of country compacts, 2) players, which refer all entities and individuals who contribute to the decisions made, 3) processes, which describes the different channels and approaches those players take in exerting their decision making or advisory power, and 4) products, which represents a wide variety of tools and instruments developed over the past years that are used by players to shape priority setting, such as SWAPs, Sector Investment Plans (SIPs), Budget Support, National Health Plans, National Strategies, disease specific plans, international evidence, and among others analytic tools, for example One Health Tool (see Fig. 2).

\section{Note}

The arrows in Processes suggests the direction of influence. Coordination/consultation is used by the local government to solicit opinions, while recommendation and conditioned financial support are influences from outside of the government. Political power, collaborative planning and political dialogues can work in both ways.

Interview Data:

A total of 21 in-depth interviews were conducted ( 6 in Ethiopia, 10 in Nigeria and 5 in Tanzania), with participants who were holding key positions in different institutions involved in the decision-making process at the time of the interview.

The three countries varied substantially in their economic and demographic status, as well as their level of reliance on external funding for health. Tanzania has the highest percentage of current health expenditure financed from external funding sources (32\%), followed by Ethiopia (22\%) and then Nigeria (8\%), see Table 1. 
Table 1

Key information about Ethiopia, Nigeria, and Tanzania

\begin{tabular}{|c|c|c|c|}
\hline & Ethiopia & Nigeria & Tanzania \\
\hline Income class & Low Income & Lower-Middle Income & Low Income \\
\hline $\begin{array}{l}\text { GDP per capita (current } \$ \text {, } \\
\text { 2018) }\end{array}$ & 772.3 & $2,028.20$ & $1,061.00$ \\
\hline Population size (2018) & $109,224,560$ & $195,874,740$ & $56,318,350$ \\
\hline $\begin{array}{l}\text { External funding for } \\
\text { health as a \% of current } \\
\text { health expenditure (2017) }\end{array}$ & 22.11 & 7.91 & 31.82 \\
\hline $\begin{array}{l}\text { Number of interviews } \\
\text { conducted }\end{array}$ & 7 & 10 & 5 \\
\hline \multirow[t]{5}{*}{ Name of institutions } & $\begin{array}{l}\text { Federal Ministry } \\
\text { of Health }\end{array}$ & $\begin{array}{l}\text { Ministry of Women } \\
\text { Affairs and Social } \\
\text { Development }\end{array}$ & Ministry of Health \\
\hline & $\begin{array}{l}\text { Ministry of } \\
\text { Finance and } \\
\text { Economic } \\
\text { Development }\end{array}$ & $\begin{array}{l}\text { Oyo State Ministry of } \\
\text { Health }\end{array}$ & $\begin{array}{l}\text { Ministry of Finance and } \\
\text { Planning }\end{array}$ \\
\hline & & $\begin{array}{l}\text { Oyo State Primary } \\
\text { Health Care Board }\end{array}$ & $\begin{array}{l}\text { President Office-Regional } \\
\text { and Local Government } \\
\text { Authority (PORALG) }\end{array}$ \\
\hline & & $\begin{array}{l}\text { Oyo State Health } \\
\text { Insurance Agency }\end{array}$ & $\begin{array}{l}\text { National AIDS Control } \\
\text { Program }\end{array}$ \\
\hline & & $\begin{array}{l}\text { Tuberculosis and } \\
\text { Leprosy Control } \\
\text { Programme for Oyo } \\
\text { State }\end{array}$ & $\begin{array}{l}\text { National TP \& Leprosy } \\
\text { Program }\end{array}$ \\
\hline $\begin{array}{l}\text { *Source of Data: The Wor } \\
\text { applied. }\end{array}$ & nk Database, & /data.worldbank.ors & most recent year was \\
\hline
\end{tabular}

Contextual features in Ethiopia, Nigeria and Tanzania

Each of the 4 layers of framework, which we used as the organizing themes - principles, players, processes, and products - informs the analysis of the priority setting process from a different angle. Keywords deemed relevant to each theme were used to search through the transcripts or interview notes. The context, where the keywords were mentioned was analyzed to identify how and where in the decisionmaking process a particular theme played a role.

Table 2 illustrates how each layer of the framework played a role in the priority setting process. Factors with major influence were marked in green, while factors with minor or no influence were marked in red. 
Table 2

Themes mentioned by government officials in Ethiopia, Nigeria, and Tanzania, for the priority setting process

\begin{tabular}{|c|c|c|c|}
\hline & Ethiopia & Nigeria & Tanzania \\
\hline \multirow[t]{2}{*}{ Principles } & $\begin{array}{l}\text { Paris Declaration and Accra } \\
\text { Agenda was referred to as } \\
\text { one of the international } \\
\text { agreements based on which } \\
\text { government organize their } \\
\text { negotiations. }\end{array}$ & $\begin{array}{l}\text { The Paris Declaration, } \\
\text { the Millennium } \\
\text { Development Goals } \\
\text { and the Sustainable } \\
\text { Development Goals } \\
\text { were not mentioned } \\
\text { during the interview. }\end{array}$ & $\begin{array}{l}\text { Due to the limited data } \\
\text { retrieved from the } \\
\text { interviews, no principles } \\
\text { were revealed in the notes } \\
\text { of the interviewer. }\end{array}$ \\
\hline & $\begin{array}{l}\text { International, bilateral, or } \\
\text { inter-organizations } \\
\text { agreements signed with local } \\
\text { government, such as the } \\
\text { International Health } \\
\text { Partnership country compact } \\
\text { surely played an important } \\
\text { role. }\end{array}$ & $\begin{array}{l}\text { Attending international } \\
\text { conferences is a way } \\
\text { for them to perceive } \\
\text { ideas for priority } \\
\text { setting, as well as } \\
\text { referencing guidelines } \\
\text { established by } \\
\text { international } \\
\text { organizations. }\end{array}$ & \\
\hline \multirow[t]{2}{*}{ Players } & $\begin{array}{l}\text { The most frequently } \\
\text { mentioned players are } \\
\text { bilateral agencies: "donor(s)" } \\
\text { or "development partner(s)" } \\
\text { were mentioned } 70 \text { times. }\end{array}$ & $\begin{array}{l}\text { Top leaders were } \\
\text { mentioned at unusually } \\
\text { high frequency in } \\
\text { Nigeria. Specific leader } \\
\text { positions were } \\
\text { mentioned, such as } \\
\text { "directors/directorate", } \\
\text { "governor", and } \\
\text { "commissioners". }\end{array}$ & $\begin{array}{l}\text { Top leaders and other } \\
\text { governmental } \\
\text { departments were } \\
\text { mentioned the most } \\
\text { during the interviews. } \\
\text { Especially that the } \\
\text { influence of top leaders, } \\
\text { represented by Presidents } \\
\text { Office Regional } \\
\text { Administration and Local } \\
\text { Government (PORALG), } \\
\text { plays an important role in } \\
\text { the priority setting } \\
\text { process. }\end{array}$ \\
\hline & $\begin{array}{l}\text { The second most frequently } \\
\text { mentioned players are } \\
\text { government } \\
\text { departments/ministries: } \\
\text { "Government" or } \\
\text { "governmental" was } \\
\text { mentioned } 40 \text { times. }\end{array}$ & $\begin{array}{l}\text { Amongst all domestic } \\
\text { non-governmental } \\
\text { players, hospitals are } \\
\text { much more involved in } \\
\text { priority setting than } \\
\text { other organizations. } \\
\text { Regular visits and } \\
\text { frequent meetings were } \\
\text { scheduled with doctors } \\
\text { and administrators } \\
\text { from hospitals to hear } \\
\text { their recommendations } \\
\text { on what is needed. }\end{array}$ & $\begin{array}{l}\text { Bilateral aid agencies are } \\
\text { the biggest influencer } \\
\text { from outside. Specific } \\
\text { names of bilateral } \\
\text { agencies were also } \\
\text { mentioned, usually in } \\
\text { scenarios where those } \\
\text { agencies acted outside } \\
\text { the coordinated efforts. }\end{array}$ \\
\hline
\end{tabular}

Note: Factors with major influence were marked in green, while factors with minor or no influence were marked in red. 


\begin{tabular}{|c|c|c|c|}
\hline & \multirow[t]{2}{*}{ Ethiopia } & \multirow{2}{*}{$\begin{array}{l}\text { Nigeria } \\
\text { Donor organizations } \\
\text { are still important } \\
\text { stakeholders, such as } \\
\text { USAID. Multilateral } \\
\text { organizations, } \\
\text { especially UNICEF and } \\
\text { WHO are also very } \\
\text { actively involved with } \\
\text { the priority setting } \\
\text { process. }\end{array}$} & \multirow{2}{*}{$\begin{array}{l}\text { Tanzania } \\
\text { NGOs was mentioned } \\
\text { once during the interview } \\
\text { and indicated little } \\
\text { influence on the policy } \\
\text { making process. No } \\
\text { multilateral agencies were } \\
\text { mentioned. }\end{array}$} \\
\hline & & & \\
\hline \multirow[t]{3}{*}{$\backslash$ Processes } & $\begin{array}{l}\text { The most frequently } \\
\text { mentioned approach is } \\
\text { "collaborative planning"; } \\
\text { "stakeholder(s)", or } \\
\text { "stakeholder(s)" were } \\
\text { mentioned } 35 \text { times, and } \\
\text { "joint" or "jointly" were } \\
\text { mentioned } 8 \text { times. }\end{array}$ & $\begin{array}{l}\text { The most frequently } \\
\text { mentioned process is } \\
\text { "collaborative } \\
\text { planning": collaborate } \\
\text { or collaboration were } \\
\text { mentioned } 8 \text { times, } \\
\text { "joint" } 32 \text { times, and } \\
\text { "stakeholders" } 11 \text { times. }\end{array}$ & $\begin{array}{l}\text { The most frequently } \\
\text { mentioned process is } \\
\text { "collaborative planning": } \\
\text { "participate" or } \\
\text { "participation" were } \\
\text { mentioned } 7 \text { times, and } \\
\text { "stakeholders" } 3 \text { times. }\end{array}$ \\
\hline & $\begin{array}{l}\text { It was followed by } \\
\text { "coordination/consultation" } \\
\text { and "political dialogue", with } \\
\text { the added sum of all key } \\
\text { words to about } 20 \text { times. }\end{array}$ & $\begin{array}{l}\text { "political dialogue" is } \\
\text { also common: } \\
\text { "negotiation" was } \\
\text { mentioned } 6 \text { times. } \\
\text { It is very common for } \\
\text { the government of } \\
\text { Nigeria to take a } \\
\text { leading role in } \\
\text { coordinating the } \\
\text { external funds. }\end{array}$ & $\begin{array}{l}\text { The second most } \\
\text { frequently mentioned is } \\
\text { "political dialogue", either } \\
\text { in the forms of discussion } \\
\text { (1) or negotiation (3). }\end{array}$ \\
\hline & $\begin{array}{l}\text { Negotiation is the most used } \\
\text { way to solve disagreements } \\
\text { than others. It was mentioned } \\
13 \text { times during the } \\
\text { interviews, compared to } 2 \\
\text { times of "diplomatic" } \\
\text { measures, and } 7 \text { times of } \\
\text { discussion(s). }\end{array}$ & & $\begin{array}{l}\text { Coordination/consultation } \\
\text { is mentioned to a less } \\
\text { extent, where government } \\
\text { departments played a } \\
\text { leading role, rather than } \\
\text { being a participatory } \\
\text { member of the process. }\end{array}$ \\
\hline
\end{tabular}

Note: Factors with major influence were marked in green, while factors with minor or no influence were marked in red. 


\begin{tabular}{|c|c|c|c|}
\hline & Ethiopia & Nigeria & Tanzania \\
\hline \multirow[t]{3}{*}{ Products } & $\begin{array}{l}\text { National or sector specific } \\
\text { development/strategic plans } \\
\text { are used more often than } \\
\text { others: "Growth and } \\
\text { Transformation Plan (GTP)" } \\
\text { was mentioned } 22 \text { times, and } \\
\text { its health sector derivative } \\
\text { "Health Sector } \\
\text { Transformation Plan (HSTP)" } \\
\text { was mentioned } 15 \text { times, and } \\
\text { they are the directing } \\
\text { documents for other tools } \\
\text { used in later stage of the } \\
\text { planning as well. }\end{array}$ & $\begin{array}{l}\text { The government } \\
\text { departments involved } \\
\text { in priority setting } \\
\text { processes used } \\
\text { analysis, evidence and } \\
\text { experiences very } \\
\text { frequently for their } \\
\text { decision making: data } \\
\text { was mentioned } 40 \\
\text { times, statistics } 5 \text { times } \\
\text { and evidence } 5 \text { times. }\end{array}$ & $\begin{array}{l}\text { The Health Sector } \\
\text { Strategic Plans (HSSP), } \\
\text { mentioned } 11 \text { times, } \\
\text { served as a } \\
\text { restriction/direction within } \\
\text { the government, but were } \\
\text { also regarded as a } \\
\text { direction from the civil } \\
\text { society. }\end{array}$ \\
\hline & $\begin{array}{l}\text { Data analytics and } \\
\text { Experiences were also } \\
\text { frequently mentioned: } \\
\text { "evidence(s)" was mentioned } \\
15 \text { times, while } \\
\text { "experience(s)" was } \\
\text { mentioned } 3 \text { times. }\end{array}$ & $\begin{array}{l}\text { The 5-year National } \\
\text { Development/Strategic } \\
\text { Plans and its } \\
\text { subsequent strategic } \\
\text { working plans for } \\
\text { health sector were also } \\
\text { referenced } 19 \text { times as } \\
\text { having a strong } \\
\text { influence, if not the } \\
\text { deciding factor in } \\
\text { priority setting. }\end{array}$ & $\begin{array}{l}\text { SWAPs were mentioned } 3 \\
\text { times by government } \\
\text { officials as a useful } \\
\text { international guideline for } \\
\text { facilitating dialogues } \\
\text { between governments and } \\
\text { donors. }\end{array}$ \\
\hline & $\begin{array}{l}\text { A few other products were } \\
\text { also mentioned, such as } \\
\text { "United Nation Development } \\
\text { Assistant Framework } \\
\text { (UNDAD)", "One Health Tool" } \\
\text { and "Marginal Budget } \\
\text { Bottlenecks". }\end{array}$ & & \\
\hline
\end{tabular}

Principles of guidance:

Due to limited data retrieved from interviews conducted in Tanzania for the analysis of principles, we were only able to compare the country of Ethiopia and Nigeria on what principles are used. International agreements, including Paris Declaration and Accra Agenda, as well as International Health Partnership country compact certainly played important roles in the priority setting process in Ethiopia:

"...Based on different international declaration such as the Paris and Accra declarations the government negotiates by prioritizing the national interest." (one government official from Ministry of Finance and Economic Development (MoFED), Ethiopia)

"Since different agreements are signed between the funder and the government, disagreements are less to happen." (one government official from MoFED, Ethiopia) 
In contrast, none of those principles were mentioned by interviewees in Nigeria. Instead, different officials agreed that attending international conferences was a way for them to perceive ideas for priority setting, as well as reading guidelines established by international organizations:

"The federal ministry of women affairs normally organizes council meetings, in that place we prepare a lot of proposals and prepare for what we'll do the coming year. Aside from that, every March, they normally attend the U.N status of women in New York. So, they come with new things by that time based on global focus." (one government official from the Ministry of Women Affairs and Social Development, Nigeria)

"Another thing is we can look at the WHO guideline and seek for approval along with this guideline that is if the policy is domesticated and accepted in Nigeria" (one government official in charge of Communicable Diseases, HIV/AIDS, and TB [tuberculosis], Nigeria)

Players involved:

The most frequently mentioned players in Ethiopia and Tanzania were bilateral agencies, followed by government departments/ministries. "donor(s)" or "development partner(s)" were mentioned 70 times, while "Government" or "governmental" was mentioned 40 times during the 7 interviews in Ethiopia. The context in which bilateral agencies were mentioned depicts a spectrum of roles they were playing in priority setting. In most cases, they were mentioned together with other stakeholders, as a member of the collaborative planning process:

"...Based on the revised policy the government sets sector-based plans and in consultation with different stakeholders including donors." (one government official from MoFED, Ethiopia)

"HSHSP [Health Sector HIV and AIDS Strategic Plan] IV includes both GOT [Government of Tanzania] and donor priorities as it is developed in a participatory manner." (one government official from Ministry of Health, Community Development, Gender, Elderly and Children (MOHCDGEC), Tanzania)

In other cases, bilateral aid agencies acted alone, but were also following the national plan of local governments:

"So based on our Growth and Transformation Plan, donors will provide support by aligning with the nationally set priorities and local agendas." (one government official from MoFED, Ethiopia)

A few scenarios were also mentioned when conflicts arose between local governments and donor organizations:

"the donor may request to use its own consultant to work different activities while the Ministry can do it with the available staff, this causes a conflict of interest between the two." (one government official from MoFED, Ethiopia) 
In Nigeria, however, top leaders were mentioned at unusually high frequency. Specific leader positions were mentioned, such as "directors/directorate", “governor", and "commissioners". In Tanzania, top leaders, represented by Presidents Office Regional Administration and Local Government (PORALG), also played an important role in the priority setting process:

"But, in the Ministry of Health which happens to be the mother of all related agencies, so, it is the Director of Administration and Supplies, they are saddled with that exercise. He is the one that will write a memo regarding that and make a request." (one government official from Oyo State Ministry of Health, Nigeria)

"For instance, the Ministry of Health has been able to convince the permanent secretary and the commissioner for health that we need this much resources to do something." (one government official from the Malaria Program, Nigeria)

Hospitals in Nigeria were much more involved in priority setting than other organizations. Regular visits and frequent meetings were scheduled with doctors and administrators from hospitals to hear their recommendations on what is needed:

"Not only that, but we also meet with our Doctors in our various hospitals once every month, first Friday to be precise. It is a technical meeting where they give us a report of what has happened in the various hospitals in the last month. They help us to know the disease pattern, know the area we need to focus and give us the ability to compare the hospitals or facilities where their health insurance with facilities or hospitals where there is no health insurance." (one staff from Oyo State Health Insurance Agency)

Donor organizations were still important stakeholders in Nigeria, such as the United States Agency for International Development (USAID), but to a less extent compared to Ethiopia and Tanzania. All three cases indicated that non-governmental organizations (NGOs) and multilateral agencies had little direct influence over the priority setting process. However, they could influence other themes as described below.

Processes utilized:

Ethiopia, Nigeria, and Tanzania shared the feature that "collaborative planning" was the most frequently mentioned process in priority-setting, which involved multiple stakeholders, and each of them played a relatively equal role in decision making:

"All of the mentioned stakeholders will also participate in decision making and agenda prioritization but the main role in agenda-setting is led by FMOH." (one government official from Federal Ministry of Health (FMoH), Policy and Planning, Ethiopia)

"They always bring their work plan which at times may not suit our challenges. But this time around, both of us will sit down and look at their work plan and look at our work plan and we merged them." (one government official from Oyo State Ministry of Health, Nigeria) 
"Annual stakeholders meeting is a forum for all partners, implementers and beneficiaries to discuss issues related to TB and Leprosy including the sharing of annual operational plans." (one government official from National TB and Leprosy Programme (NTLP)-MOHCDGEC, Tanzania)

"Political dialogue and "coordination/consultation" initiated by local governments were also quite common in all three countries. In Ethiopia, political dialogue usually takes the form of negotiation, while in Nigeria, it was mentioned as meetings and discussions, and in Tanzania, as discussions and negotiations:

"During setting priorities, the government takes the lead however consultations are commonly requested from different stakeholders to finalize and approve priorities." (one government official from MoFED, Ethiopia)

"...the major problem is the vacuum called 'meeting, discussion' before the final approval of the project." (one government official from the Ministry of Women Affairs and Social Development, Nigeria)

"MOHCDGEC and PORALG had different views on this issue and through dialogue, a consensus was reached." (one government official from Directorate of Policy and Planning (DPP)-MOHCDGEC, Tanzania)

"Dialogue is the approach used to address any disagreements. A good example is when the PORALG wanted to use the balance from unused HBF [Health Basket Funds] funds for upgrading or putting up a new infrastructure for health facilities. The Sector ministry and Donors had a different opinion, but after repeated dialogue, all parties agreed to use the funds for an infrastructure upgrade. (one government official from PORALG, Tanzania)

Political power was also used in the process. It includes diplomatic power through going up the government hierarchy and judiciary power that imposes legal constraints on certain behaviors:

Conflicts that arise mostly due to implementation (if the project implementation deviates from the directive and proclamation), are primarily resolved by negotiation. If the dispute is not resolved by negotiation, then it will be referred to be handled by the federal court. (one official from the Social Charity organizations, Ethiopia)

Conditioned financial support was mentioned in all three cases, suggesting that donor influence through funding was still very prevalent:

"The first word I will say he who has the piper dictates the tune, no matter what your priorities are by the time someone is bringing money to help you but then these are the ways at which you can go, the best you can do is to see how well their most mode of operation will end up suiting your own expectation." (one government official from Oyo State Ministry of Health, Nigeria)

"Partners would in many cases come up with innovations that are not included in HSHSP IV and would like to fund pilots." (one government official from National AIDS Control Program-MOHCDGEC, Tanzania) 
Products used:

In all three cases, national or sector-specific development/strategic plans were the most frequently used product in guiding priority setting process. They were called "Growth and Transformation Plan (GTP)" and "(5- year) Health Sector Transformation Plan (HSTP)" in Ethiopia, "5-year National Development/Strategic Plans" in Nigeria, and "Health Sector Strategic Plan (HSSP)" in Tanzania:

"Currently there are around 28 United Nations (UN) agencies. These agencies have a framework for budgeting and implementing planned activities. United Nations Development Assistant Framework (UNDAF) is a framework which will be signed by all UN agencies and all are under this document. Using this framework country-specific projects will be designed for five years based on the sector plan or GTP, for UNICEF the plan will be following the HSTP." (one government official from Multilateral collaboration, MoFED, Ethiopia)

"there must be a memorandum of understanding, this MOU is review by the desk officer to see if it goes with what is (in) the strategic plan." (one government official in charge of Communicable Diseases, including HIV/AIDS, TB, Nigeria)

"The HSSP guide the sector and all stakeholders. It is a promise to the public by the Government." (Notes from a policy consultant with the Government of Tanzania for the interview with a government official from DPP-MOHCDGEC, Tanzania)

In Ethiopia, priority setting took a "cascade"-like hierarchical process, where each level of priority needed to be set based on or following the agreement or principles finalized by upper-level government bodies:

"Five-year strategic plan is set and prioritized issues including resource gaps are addressed in the strategic plan. The mother document is the GTP and every other thing evolved from this document." (one official from FMoH, Ethiopia)

Data analytics and Experiences were also frequently mentioned in both Ethiopia and Nigeria, which included epidemiological data, demographic data, economic analysis, etc.:

"Disease burden is reviewed during planning, including mortality, morbidity, impact on the economy and also human right issues, then alternative interventions will be proposed and finally will be prioritized." (One government official from FMoH, Resource mobilization, Ethiopia)

"Zamfara may tell you they have understood there are seasonal variations... I cannot attempt that in Oyo State. Because I know malaria in my state is year-round." (one government official from the Malaria Program, Nigeria)

In Tanzania, SWAPs were mentioned multiple times by government officials as a useful international instrument for facilitating dialogues between governments and donors: 
"Tanzania has a functioning SWAP dialogue structure that puts in use the above." (one government official from DPP-MOHCDGEC)

Main findings from cross-country comparative analysis:

Cross country analysis revealed similarities as well as differences. First, there was noticeable variation in the principles used and players involved in the priority-setting process in Nigeria, a lower-middle-income country where external funding accounted for less than $10 \%$ of the current total health expenditure, as compared with Ethiopia and Tanzania, both low-income countries, where external funding accounted for $22 \%$ and $32 \%$ of the total health expenditures respectively.

In Nigeria, principles appeared in more informal ways, for example the principles garnered from attending international conferences. While in Ethiopia, formal principles, such as the Paris Declaration, the Millennium Development Goals, or the Sustainable Development Goals, as well as signed agreements under the International Health Partnership were mentioned as their guiding principles. In Nigeria, local government, especially the top leaders took a more direct role in setting priorities in the health sector. However, in both Tanzania and Ethiopia, bilateral aid agencies were mentioned most frequently when asked to describe the priority setting process. Non-governmental organizations remained as very marginalized players in decision-making related to resource allocation in health.

In all the three countries there was more convergence with processes and products. Across the three study countries: 1) collaborative planning was the most commonly used process, and 2) the Health Sector or National Strategic Plan were the most commonly utilized products in the priority-setting process.

The findings suggest that multiple stakeholders working around one national plan was how priorities were established in these countries. Political dialogue was also frequently used by all three countries as a process to reach an agreement with other stakeholders and/or to resolve an existing conflict of ideas. This took the form of discussions, meetings, and negotiations.

In addition to Health Sector Plans of Strategies, evidence and experiences were two other products used in setting health priorities, more prominently in Ethiopia and Nigeria than Tanzania.

There were minor differences in the processes and products used across the three case countries: consultation and coordination were mentioned more often in Ethiopia, where the government assumed a more leading role were mentioned, than in Nigeria and Tanzania. In Ethiopia, there were also other products mentioned as useful tools: "United Nations Development Assistant Framework", "One Health Tool" and "Marginal Budget Bottlenecks". In Tanzania, Sector Wide Approaches were mentioned multiple times.

\section{Discussion:}


We developed a new analytical framework to explore priority setting processes in health and applied it to Ethiopia, Nigeria, and Tanzania. We conducted a comparative analysis to understand which principles were used to guide the priority setting process the extent of engagement by different players, and the application of different processes, and products.

The analytic framework was developed to examine priority setting as a dynamic process where each component interacts with each other to shape decisions and not to present a "laundry list" of institutions and persons involved in priority setting, as described by previous scholars (35).

Findings from the three case studies reveal that donors and top government leaders still remain the most influential players in priority setting in the health sector. Involvement of civil society organizations is very low. Our findings, corroborate those from earlier studies (36) which demonstrated that public engagement remains elusive despite active attempts from donors and governments to include civil society in decisionmaking processes.

Comparative analysis across the three country cases seemed to suggest that in countries where a higher proportion of health expenditure is from external sources, donor agencies tend to have stronger influence in the priority setting process. Recent case studies by other scholars in Cambodia and Pakistan (37)explained how donors influence the agenda setting of recipient countries, mostly through their control over direct and indirect financial and political influences - a finding also revealed by our study.

Collaborative planning and political dialogue were the most commonly used process by local governments, with consultation used to a lesser extent. This finding is in line with various models proposed for the priority-setting process (38-40)which emphasizes inclusiveness, transparency and broader stakeholder engagement. Two other processes could be used by recipient governments to enhance the priority setting process and ensure a more balanced approach. First, by actively identifying international recommendations that support their arguments on why certain areas should be included as priorities. Second, by establishing strong local coalitions, by engaging multiple sources of political power, for example higher-level government leaders, and by drawing on the legal and regulatory limits set by other government departments, and public opinion.

National strategic plans for health have been recommended by World Health Organization (41) as a useful tool in establishing health priorities, where country level implementation is not always satisfactory(42). Our case studies reveal that all three countries have used a national strategic plan as the guiding product for all levels of decision making. A national strategic plan was the most frequently mentioned product among all others.

Use of data can be a highly effective tool in persuading other stakeholders to agree with the national plan: local governments can invest in data-generating skills within the organization or with partners. Past experiences are also powerful in influencing the design and implementation of health actions, especially where data are either scarce or too simplistic for real-world applications. Local government could make 
better use of past experiences by establishing a good recording system of what happened, whether an intervention or policy worked or not, and why.

In summary, none of the three countries were actively involving all the players in their priority setting process, which suggests a large unfulfilled potential to build and expand country-level alliances. In particular, the players currently underutilized included other legal and regulatory departments within the government, other domestic players and multilateral agencies, and international entities.

The COVID-19 pandemic has posed a series of major challenges to the health systems in LMICs(43). The response to COVID-19 is consuming large amounts of public health resources with potentially negative impact on existing health delivery programs, especially for vulnerable populations including women and children $(44,45)$. In the foreseeable near future, priority setting process for health in LMICs will continue to be swayed towards health emergencies, compromising efforts in maintaining or expanding routine health programs aimed at addressing other local needs. Decision makers are in more need of better tools in making sure resources are allocated in just, efficient and sustainable manner to locally relevant needs.

Our study has limitations. The small sample size in each country might render the data incomplete and thus may miss key features that could be revealed by interviewing government officials from other departments. Further, the study did not explore in depth the interactive nature of each element within this framework, for example the correlation of use of certain processes with higher power presented by local governments or bilateral agencies, or the association of active engagement of certain players with more power to the local government in collaborative planning. However, notwithstanding the limitations, the study reveals novel findings and identifies new questions for future research that could help answer them.

\section{Conclusions:}

Our analysis reveals that in the countries analyzed, health strategies and priorities are not made by selecting from a list of options available to decision-makers, but is a dynamic process that involves multiple pathways that interact with each other and where each pathway and their interaction contribute to the outcome in its own way.

This article presented how a novel framework can be used in analyzing the priority setting process in countries that receive ODA and in comparative analysis. The analytical framework enabled the identification of shared features, as well as variances in priority setting process across countries. The comparative analysis has provided insights into what resources and strategies local governments could utilize to ensure greater engagement and more prominent role in priority setting to balance donor power and improve the effectiveness of the overseas development assistance for health.

\section{Abbreviations}




\begin{tabular}{|c|c|}
\hline AIDs & Acquired Immunodeficiency Syndrome \\
\hline DPP & Directorate of Policy and Planning \\
\hline $\mathrm{FMoH}$ & Federal Ministry of Health \\
\hline GOT & Government of Tanzania \\
\hline GTP & Growth and Transformation Plan \\
\hline HBF & Health Basket Funds \\
\hline HIV & Human Immunodeficiency Virus \\
\hline HSHSP & Health Sector HIV and AIDS Strategic Plan \\
\hline HSSP & Health Sector Strategic Plan \\
\hline HSTP & Health Sector Transformation Plan \\
\hline $\mathrm{IHP+}$ & International Health Partnership Plus \\
\hline LMICs & Low- and Middle-Income Countries \\
\hline MDGs & Millennium Development Goals \\
\hline MoFED & Ministry of Finance and Economic Development \\
\hline MOHCDGEC & Ministry of Health, Community Development, Gender, Elderly and Children \\
\hline MOU & Memorandum of Understanding \\
\hline NGOs & Non-Governmental Organizations \\
\hline NTLP & National TB and Leprosy Programme \\
\hline ODA & Overseas Development Assistance \\
\hline PORALG & Presidents Office Regional Administration and Local Government \\
\hline PORALG & President's Office Regional and Local Government \\
\hline SIPs & Sector Investment Plans \\
\hline SWAPS & Sector Wide Approaches \\
\hline TB & Tuberculosis \\
\hline UN & United Nations \\
\hline UNDAF & United Nations Development Assistant Framework \\
\hline USAID & United States Agency for International Development \\
\hline WHO & World Health Organization \\
\hline
\end{tabular}




\section{Declarations}

Ethical approval and consent to participate Ethics approval were initially obtained from Harvard T.H. Chan School of Public Health Office of Human Research Administration with an exemption for additional ethical review (reference number: IRB18-0455). Local ethical approvals were obtained from Addis Continental Institute of Public Health Institutional Ethical Review Board (reference number: 0029), Social Science and Humanities Research Ethics Committee, University of Ibadan (reference number: UI/SSHREC/2019/0006), National Institute for Medical Research of The United Republic of Tanzania and Ministry of Health, Community Development, Gender, Elderly \& Children of the United Republic of Tanzania (reference number: NIMR/HQ/R.8a/Vol IX/2843), by respective country research teams. All participants signed an informed consent form before being interviewed with an option of being recorded or not. All methods were carried out in accordance with relevant guidelines and regulations.

Consent for publication Not applicable

Availability of data and materials The datasets used and/or analysed during the current study are available from the corresponding author on reasonable request.

Competing interests The authors declare that there are no conflicts of interest.

Funding We are also grateful to Bill and Melinda Gates Foundation Beijing Office for providing the funding support and made this study possible (Contract ID:OPP1175963).

Author's contributions XJK and WF conceptualized the study design with input from YB, JK and AO. XJK and $Y L$ conducted the systematic scoping review and extracted initial themes, which was later used to develop the framework by XJK, with guidance from RA and WF. FW, DM and AC coordinated the data collection and analysis in each country. All authors contributed to the development of the manuscript, and have read and approved the final version of the manuscript that was submitted.

Acknowledgements The authors are grateful to Dr. Yahya Ipuge for his input in collecting and summarizing interview data in Tanzania, and to Prof. Peter Berman for his insightful feedback to the study design.

\section{References}

1. Agaba E. Funding the promise: monitoring Uganda's health sector financing from an HIV/AIDS perspective. African health sciences. 2009;9:581-5.

2. Harper SE. The Fungibility of Aid Earmarked for HIV/AIDS Control Programs. World Development. 2012;40(11):2263-74.

3. Kakaire T, Schlech W, Coutinho A, Brough R, Parkes-Ratanshi R. The future of financing for HIV services in Uganda and the wider sub-Saharan Africa region: should we ask patients to contribute to the cost of their care? BMC public health. 2016;16. 
4. Batana YM. Aid and Poverty in Africa: Do Well-being Measures Understate the Progress? African Development Review-Revue Africaine De Developpement. 2010;22(3):452-69.

5. Floyd K, Fitzpatrick C, Pantoja A, Raviglione M. Domestic and donor financing for tuberculosis care and control in low-income and middle-income countries: an analysis of trends, 2002-11, and requirements to meet 2015 targets. Lancet Global Health. 2013;1(2):E105-E15.

6. de Jongh TE, Harnmeijer JH, Atun R, Korenromp EL, Zhao JK, Puvimanasinghe J, et al. Health impact of external funding for HIV, tuberculosis and malaria: systematic review. Health policy and planning. 2014;29(5):650-62.

7. Ataya N, Aluttis C, Flahault A, Atun R, Haines A. Improving the assessment and attribution of effects of development assistance for health. The Lancet. 2014;384(9961):2256-9.

8. OECD. Paris Declaration and Accra Agenda for Action. oecd.org; 2008.

9. Woods N. Whose aid? Whose influence? China, emerging donors and the silent revolution in development assistance. International Affairs. 2008;84(6):1205-21.

10. Pfeiffer J, Gimbel S, Chilundo B, Gloyd S, Chapman R, Sherr K. Austerity and the "sector-wide approach" to health: The Mozambique experience. Social Science \& Medicine. 2017;187:208-16.

11. Aryeetey R, Holdsworth M, Taljaard C, Hounkpatin WA, Colecraft E, Lachat C, et al. Evidence-informed decision making for nutrition: African experiences and way forward. Proceedings of the Nutrition Society. 2017;76(4):589 - 96.

12. Ashwell $H$, Barclay L. Challenges to achieving sustainable community health development within a donor aid business model. Australian and New Zealand Journal of Public Health. 2010;34(3):320-5.

13. Eboreime EA, Nxumalo N, Ramaswamy R, Eyles J. Strengthening decentralized primary healthcare planning in Nigeria using a quality improvement model: how contexts and actors affect implementation. Health Policy and Planning. 2018;33(6):715-28.

14. Skovdal M, Magutshwa-Zitha S, Campbell C, Nyamukapa C, Gregson S. Getting off on the wrong foot? How community groups in Zimbabwe position themselves for partnerships with external agencies in the HIV response. Globalization and health. 2017;13.

15. Barnes A, Brown GW, Harman S. Global Politics of Health Reform in Africa: Performance, Participation, and Policy Conclusion. Global Politics of Health Reform in Africa: Performance, Participation, and Policy. Palgrave Pivot2015. p. 86-98.

16. Birdsall N, Kharas H, Perakis R. The Quality of Official Development Assistance Assessment 2009: Is Aid Quality Improving? www.bropkings.edu/global: Center for Global Development; 2012.

17. Sweeney R, Mortimer D, Johnston DW. Do Sector Wide Approaches for health aid delivery lead to 'donor-flight'? A comparison of 46 low-income countries. Social Science \& Medicine. 2014;105:3846.

18. Sweeney R, Mortimer D. Has the Swap Influenced Aid Flows in the Health Sector? Health Economics. 2016;25(5):559-77. 
19. Leiderer S. Donor Coordination for Effective Government Policies? Journal of International Development. 2015;27(8):1422-45.

20. Shen AK, Farrell MM, Vandenbroucke MF, Fox E, Pablos-Mendez A. Applying lessons learned from the USAID family planning graduation experience to the GAVI graduation process. Health policy and planning. 2015;30(6):687-95.

21. Banke-Thomas A, Madaj B, Kumar S, Ameh C, van den Broek N. Assessing value-for-money in maternal and newborn health. BMJ global health. 2017;2(2).

22. Porter LE, Bouey PD, Curtis S, Hochgesang M, Idele P, Jefferson B, et al. Beyond Indicators: Advances in Global HIV Monitoring and Evaluation During the PEPFAR Era. Jaids-Journal of Acquired Immune Deficiency Syndromes. 2012;60:S120-S6.

23. Munir K, Worm I. Health systems strengthening in German development cooperation: making the case for a comprehensive strategy. Globalization and health. 2016;12.

24. Fujita M, Akabayashi A, Slingsby BT, Kosugi S, Fujimoto Y, Tanaka K. A model of donors' decisionmaking in adult-to-adult living donor liver transplantation in Japan: Having no choice. Liver Transplantation. 2006;12(5):768-74.

25. Sterck OC. What goes wrong with the allocation of domestic and international resources for HIV? Health Economics. 2018;27(2):320-32.

26. Jones A, Howard N, Legido-Quigley $\mathrm{H}$. Feasibility of health systems strengthening in South Sudan: a qualitative study of international practitioner perspectives. BMJ open. 2015;5(12).

27. Azuine RE, Singh GK, Ekejiuba SE, Ashu E, Azuine MA. Global Health Donor Presence, Variations in HIV/AIDS Prevalence, and External Resources for Health in Developing Countries in Africa and Asia. International journal of MCH and AIDS. 2014;2(2):190-9.

28. Warren AE, Wyss K, Shakarishvili G, Atun R, de Savigny D. Global health initiative investments and health systems strengthening: a content analysis of global fund investments. Globalization and health. 2013;9.

29. Borghi J, Munthali S, Million LB, Martinez-Alvarez M. Health financing at district level in Malawi: an analysis of the distribution of funds at two points in time. Health policy and planning. 2018;33(1):59-69.

30. Israr SM, Islam A. Good governance and sustainability: A case study from Pakistan. International Journal of Health Planning and Management. 2006;21(4):313-25.

31. Arksey H, O'Malley L. Scoping studies: towards a methodological framework. International Journal of Social Research Methodology. 2005;8(1):19-32.

32. Hsieh H, Shannon S. Three approaches to qualitative content analysis. Qualitative health research. 2005;15(9):1277-88.

33. Glaser BG. Basics of grounded theory analysis: Emergence vs forcing: Sociology press; 1992.

34. Strauss AL. Qualitative analysis for social scientists: Cambridge university press; 1987. 
35. Frenk J. The Global Health System: Strengthening National Health Systems as the Next Step for Global Progress. Plos Medicine. 2010;7(1).

36. Alderman KB, Hipgrave D, Jimenez-Soto E. Public Engagement in Health Priority Setting in Low- and Middle-Income Countries: Current Trends and Considerations for Policy. Plos Medicine. 2013;10(8).

37. Khan MS, Meghani A, Liverani M, Roychowdhury I, Parkhurst J. How do external donors influence national health policy processes? Experiences of domestic policy actors in Cambodia and Pakistan. Health Policy and Planning. 2018;33(2):215-23.

38. Glassman A, Chalkidou K. Priority-Setting in Health: Building Institutions for Smarter Public Spending. Center for Global Development; 2012.

39. Viergever RF, Olifson S, Ghaffar A, Terry RF. A checklist for health research priority setting: nine common themes of good practice. Health Research Policy and Systems. 2010;8.

40. Campbell S. Deliberative Priority Setting - a CIHR KT module. Canadian Institutes of Health Research; 2010.

41. Terwindt F, Rajan D, Soucat A. Priority-setting for national health policies, strategies and plans. Strategizing national health in the 21st century: a handbook: World Health Organization; 2016.

42. Afriyie DO, Nyoni J, Ahmat A. The state of strategic plans for the health workforce in Africa. Bmj Global Health. 2019;4.

43. Hopman J, Allegranzi B, Mehtar S. Managing COVID-19 in Low- and Middle-Income Countries. JAMA. 2020;323(16):1549-50.

44. Fore HH. A wake-up call: COVID-19 and its impact on children's health and wellbeing. The Lancet. 2020;8.

45. Longo E, Campos ACd, Schiariti V. COVID-19 Pandemic: Is This a Good Time for Implementation of Home Programs for Children's Rehabilitation in Low- and Middle-Income Countries? Physical \& Occupational Therapy In Pediatrics 2020;40(4):361-4.

\section{Figures}

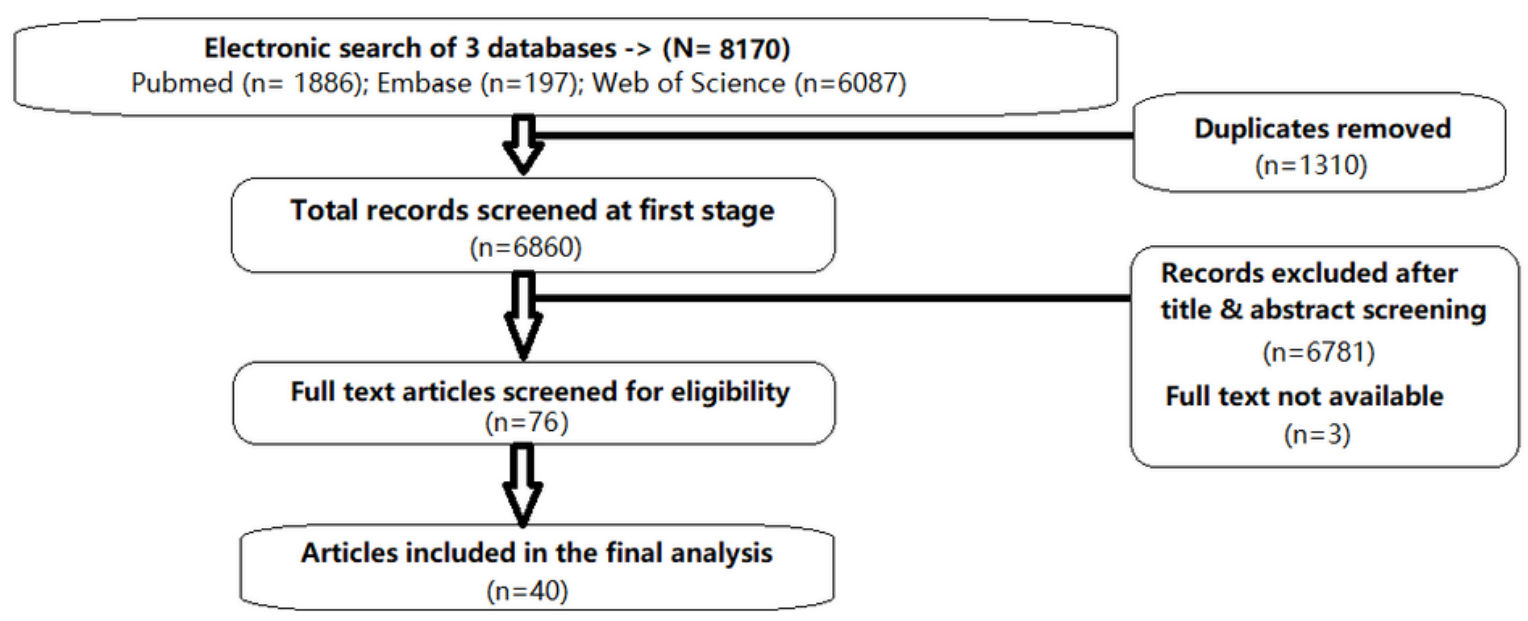


Figure 1

PRISMA chart of the scoping review
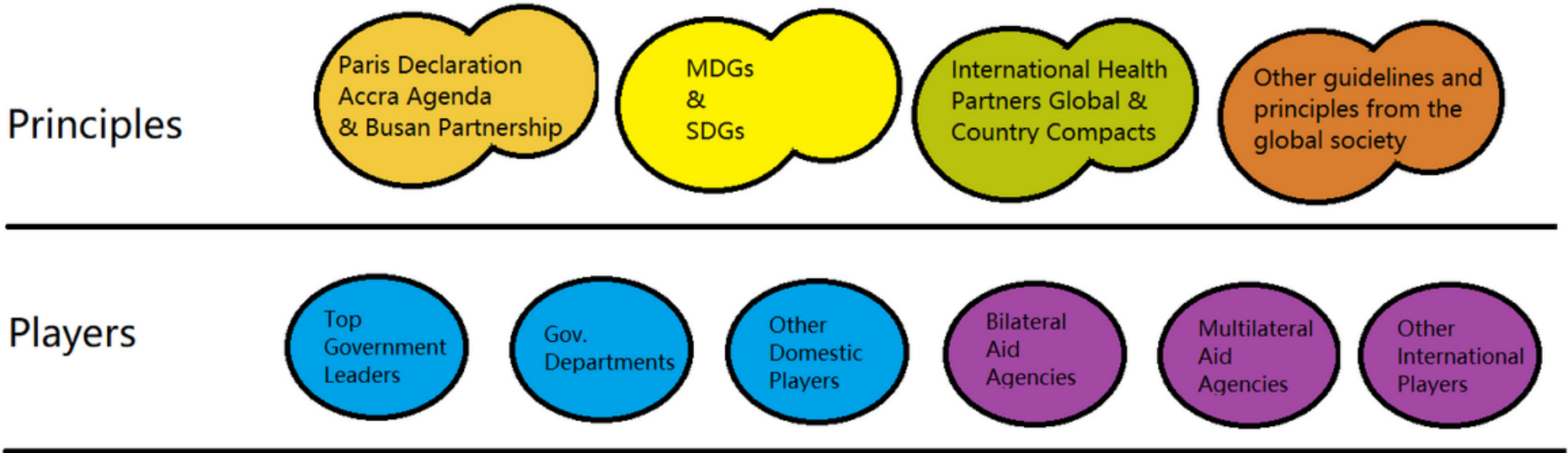

\section{Processes}
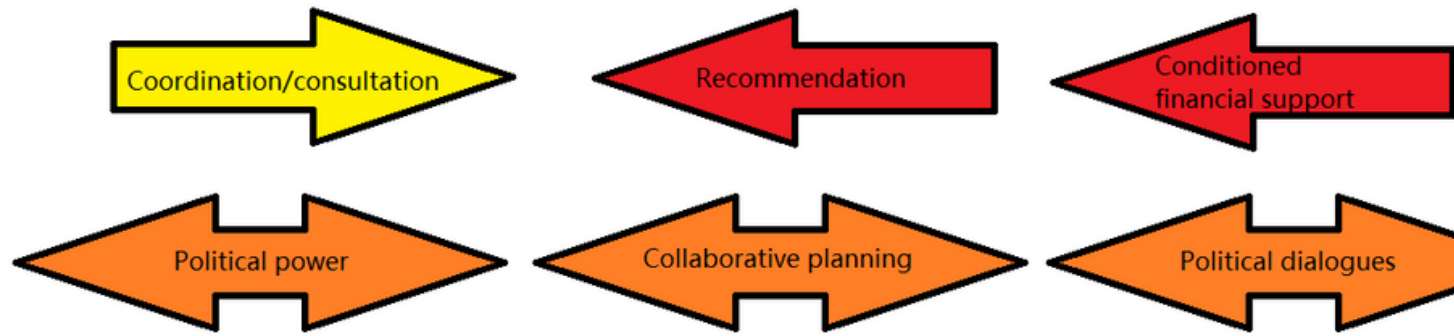

Collaborative planning

Political dialogues

Products
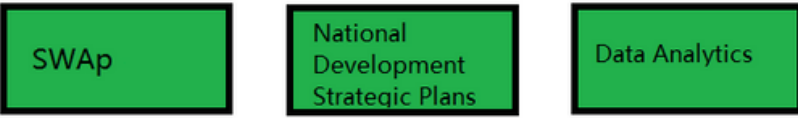

Figure 2

Framework on priority setting in health care 